\title{
SWOBODA WYBORU PEKNOMOCNIKA W UBEZPIECZENIU OCHRONY PRAWNEJ
}

Słowa kluczowe: działalność ubezpieczeniowa, regulacje unijne, ubezpieczenia gospodarcze, ubezpieczenia ochrony prawnej, swoboda wyboru pełnomocnika.

Klasyfikacja JEL: G22, K39.

Abstrakt: Swoboda wyboru pełnomocnika stanowi podstawę rozwoju ubezpieczeń ochrony prawnej. Została ona wprowadzona na gruncie regulacji europejskich w dyrektywie 87/344/EWG. Autor wskazuje praktyczne zagadnienia związane z użytymi w dyrektywie pojęciami: „pełnomocnik” oraz „etap przedsądowy”. Artykuł dotyczy także problemów prawnych i ekonomicznych związanych z próbami ograniczenia tej zasady przez wprowadzanie instytucji asysty prawnej oraz reprezentowanie ubezpieczonego bezpośrednio przez sam zakład ubezpieczeń.

\section{FREEDOM OF CHOICE OF A LAWYER}

Keywords: European regulations, freedom of choice of lawyer, insurance, insurance activity, legal exepenses insurance.

JEL Classification: G22, K39.

Abstract: The freedom to choose lawyer is a base of development of the legal expenses insurance market. It appeared on the basis of EU regulations in the 87/344/Directive regulations connected with principle of the freedom of choice of lawyer on the basis of Polish Insurance Activity Act. Author present practical issues connected with the terms used in the Directive "lawyer" and "prejudical stage". Article also refers law and econo-

Data wpłynięcia: 15.12.2012; data zaakceptowania: 24.04.2013.

* Dane kontaktowe: maciek.balcerowski@gmail.com, ul. Broniewskiego 101/121, 01-877 Warszawa, tel. 509957898. 
mic issues connected with the attempt to limit the rule of freedom to choose lawyer by introducing legal assistance and representation of the insured by the insurer.

Translated by Maciej Balcerowski

\section{II WSTĘP}

Przez ubezpieczenia ochrony prawnej należy rozumieć taką umowę ubezpieczenia, w której zakład ubezpieczeń w ramach prowadzonej przez siebie działalności gospodarczej zobowiązuje się do pokrycia kosztów toczącego się sporu, natomiast ubezpieczający zobowiązuje się do zapłacenia składki ubezpieczeniowej. W praktyce ogólne warunki ubezpieczenia precyzyjnie wskazują zarówno katalog kosztów, które ubezpieczyciel refunduje, jak i ich wysokość oraz zakres spraw, za które odpowiada. Tak rozumiane ubezpieczenie ochrony prawnej powstało w 1897 roku we Francji w ofercie Towarzystwa Ubezpieczeń Sou Medical (Janyga, Dittmajer 2005: 70). Następnie ubezpieczenie to rozwijało się we Francji oraz Szwajcarii jako ubezpieczenie skierowane do posiadaczy pojazdów mechanicznych (Vassel, Mierzejewski 2005: 34). Co ciekawe, mimo „romańskiego” rodowodu tego produktu ubezpieczeniowego, w szerokich kręgach uważa się, że jego ojczyzną są Niemcy. Ten pogląd jest o tyle uzasadniony, że jakkolwiek pierwsze ubezpieczenia powstały poza obrębem germańskiej kultury prawnej, to właśnie w jej ramach została sformułowana zasada podstawowa na gruncie nowoczesnego ubezpieczenia ochrony prawnej, a mianowicie prawo wolnego wyboru pełnomocnika. Powszechnie przyjmuje się, że to właśnie ten czynnik miał zasadnicze znaczenie dla niezwykle dynamicznego rozwoju tego ubezpieczenia w Niemczech oraz Austrii w przeciwieństwie do Wielkiej Brytanii czy samej Francji. Ta opinia była do tego stopnia mocno zakorzeniona, że znalazła wyraz w brzmieniu Dyrektywy Rady z dnia 22 czerwca 1987 roku w sprawie koordynacji przepisów ustawowych, wykonawczych i administracyjnych odnoszących się do ubezpieczenia ochrony prawnej (dalej: dyrektywa OP). Zgodnie z art. 4 dyrektywy OP państwa mają obowiązek zagwarantować swobodny wybór pełnomocnika w ramach toczącego się postępowania sądowego lub przed organem administracji.

\section{ZASADA SWOBODNEGO WYBORU PEŁNOMOCNIKA - ZNACZENIE DLA RYNKU}

U źródeł zasady swobodnego wyboru pełnomocnika leży potencjalny konflikt interesów mogący powstać między ubezpieczonym a ubezpieczycielem, który 
polega na tym, że ubezpieczyciel będzie z zasady dążył do możliwie niskokosztowej likwidacji szkody, z kolei celem ubezpieczonego będzie możliwie szybkie i korzystne rozstrzygnięcie sprawy sądowej. Należy przy tym wskazać, że ubezpieczony w większości przypadków będzie traktował wysokość wygenerowanych kosztów jako kwestię drugorzędną z uwagi na fakt, że i tak ciężar ich pokrycia zostaje przeniesiony na ubezpieczyciela (Janyga 2011: 16).

Źródła znaczenia zasady swobody wyboru pełnomocnika dla rozwoju rynku ubezpieczeń ochrony prawnej należy upatrywać w konieczności zachowania zaufania między ubezpieczonym a jego pełnomocnikiem. W sytuacji, kiedy to ubezpieczyciel „zatrudnia” pełnomocnika, jest on w pewnej mierze zdeterminowany interesem podmiotu zatrudniającego. W takim przypadku dąży on do możliwie szybkiego, a co ważniejsze - niskokosztowego rozwiązania sporu. Ubezpieczony zaś może mieć wątpliwości, w czyim interesie rzeczywiście działa pełnomocnik - jego czy też zakładu ubezpieczeń. Zasada swobody wyboru pełnomocnika pozwala na ograniczenie tego typu patologicznych sytuacji przez umożliwienie wyboru pełnomocnika „z rynku”. Nawet gdy ubezpieczony wybiera pełnomocnika polecanego przez ubezpieczyciela, co zdarza się w około $90 \%$ przypadków, de facto to ubezpieczony umocowuje swojego pełnomocnika.

Polski rynek ubezpieczeń ochrony prawnej jest rynkiem relatywnie młodym, cechującym się zarówno ogromnym tempem rozwoju, jak i potencjałem na dalsze lata. Pierwsze twierdzenie może zostać zobrazowane przez wskazanie, że w roku 2000 przypis składki w ramach ubezpieczeń grupy 17 działu II (ubezpieczenia ochrony prawnej) wynosił jedynie $0,3 \mathrm{mln}$ zł rocznie, natomiast w roku 2010 już 239,85 mln zł rocznie (KNF). Oznacza to, że rynek zwiększył się prawie 800-krotnie. Odnosząc się do drugiego stwierdzenia, należy wskazać, że w roku 2010 przypis składki z tytułu ubezpieczenia ochrony prawnej na jednego mieszkańca Polski wynosił 1,6 euro, natomiast w krajach, których rynki uznaje się za rozwinięte, taki przypis wynosił średnio 47 euro (Austria) czy 39 euro (Niemcy) (Budzisiak 2011: 8). Rynek ten staje się atrakcyjny nie tylko dla samych ubezpieczonych, oferując nawet przeciętnie sytuowanym obywatelom produkt pozwalający na pokrycie relatywnie wysokich kosztów związanych z korzystaniem z usług zawodów prawniczych i dochodzeniem roszczeń przed wymiarem sprawiedliwości, ale także dla ubezpieczycieli, gdyż od początku prowadzenia statystyk dla tego ubezpieczenia możemy odnotować nadwyżkę przypisu składki nad wypłatami (KNF). Ponadto wielu praktyków rynku ubezpieczeń (Szywalski 2011: 12) uważa, że przyszłością produktów ochrony prawnej jest przyjęcie modelu tzw. komplementarności świadczonych 
usług ubezpieczeniowych. W ramach tego modelu dochodzi do „łączenia” ubezpieczeń odpowiedzialności cywilnej z ubezpieczeniami ochrony prawnej. Jakkolwiek zgodnie z art. 3 dyrektywy OP, a co za tym idzie - także z art. 14 ust. 1 Ustawy o działalności ubezpieczeniowej (dalej: udu), ubezpieczenie odpowiedzialności cywilnej nie powinno być łączone z innymi ubezpieczeniami, praktyka wskazuje na obustronne korzyści (Janyga 2011: 16). Z jednej strony, ubezpieczony może skorzystać z faktu, że w przypadku łącznej sprzedaży produktów ubezpieczyciele co do zasady obniżają koszty ubezpieczenia dołączanego. Z drugiej strony, dochodzi do rozłożenia ciężaru ryzyka przez ubezpieczyciela między dwa produkty ubezpieczeniowe. Wydaje się, że sprzedaż dwóch produktów ubezpieczeniowych - ubezpieczenia odpowiedzialności cywilnej i ubezpieczenia ochrony prawnej - jest uzasadnione tym, że de facto wielokrotnie istnieje wspólnota interesów między ubezpieczonym i ubezpieczycielem. W przypadku pozytywnego rozstrzygnięcia sporu, w ramach którego ubezpieczyciel ponosi ryzyko wyniku procesu (w razie uzyskania pozytywnego wyroku, zgodnie z art. $98 \S 1$ kodeksu postępowania cywilnego - dalej: kpc, koszty sądowe są zasądzane na rzecz strony wygrywającej), nie zachodzi ryzyko z tytułu odpowiedzialności cywilnej, co zwalnia ubezpieczyciela z obowiązku wypłaty odszkodowania z tego ubezpieczenia. Można jednak wskazać niepokojącą tendencję do „przerzucania” na ubezpieczonego części kosztów takiej obrony. Z reguły ogólne warunki ubezpieczenia przewidują bądź to jedynie częściową refundację kosztów, bądź pokrywają te koszty w ramach zryczałtowanych stawek, które w pewnych okolicznościach mogą nie wystarczyć na pokrycie kosztów rzeczywistej ochrony interesów, wobec czego brakującą kwotę uiszcza ubezpieczony. Ubezpieczyciel może także w takiej sytuacji zrezygnować z własnego udziału $\mathrm{w}$ takim postępowaniu za pomocą interwencji ubocznej.

\section{PROBLEM ASYSTY PRAWNEJ}

Przechodząc jednak do zasadniczego problemu artykułu - a więc swobody wyboru pełnomocnika - można rozpocząć od rozważenia problematyki tzw. przedprocesowej pomocy prawnej świadczonej przez ubezpieczyciela. Taka asysta prawna mieści się $\mathrm{w}$ ramach uprawnień zakładu ubezpieczeń w tym ściśle oznaczonym stadium sprawy.

W literaturze przedmiotu wielokrotnie wskazuje się, że zasygnalizowana w poprzednim akapicie pomoc prawna stanowi bądź to uzupełnienie produktu, bądź jest nakierowana na realne obniżenie kosztów świadczonej ochrony 
ubezpieczeniowej (m.in. Szywalski 2011: 12). Zazwyczaj ubezpieczyciele dodają do produktu bazowego - umowy ubezpieczenia ochrony prawnej - produkt określany informacją prawną albo assistance'em prawnym. Literatura prawnicza w przeważającej większości stoi na stanowisku, że takie działanie jest co do zasady niezgodne z prawem (m.in. Janyga 2010). Różnice sprowadzają się w praktyce do wskazania źródła tej niezgodności.

W ramach usługi assistance prawnego firmy zewnętrzne dokonują wstępnej weryfikacji konieczności udzielenia pomocy prawnej przez radcę prawnego lub adwokata. W przypadku stwierdzenia braku takiej konieczności oferują one sporządzenie opinii lub też wzorów pism dla klientów. Pozwala to na istotne obniżenie kosztów ochrony ubezpieczeniowej. Szacuje się, że nawet 95\% spraw zgłaszanych przez klientów jest likwidowanych za pomocą tej usługi. Wymierny efekt takiego działania stanowi wysoka rentowność ubezpieczeń ochrony prawnej. Na 239,85 mln pobranej składki ubezpieczeniowej w 2010 roku przypadło jedynie 7,32 mln wypłat odszkodowań (KNF). Towarzystwa ubezpieczeniowe mogą także dokonać transferu ryzyka wysokiej szkodowości w ramach usług assistance prawnego na podmioty zewnętrzne przez opłacenie zryczałtowanego wynagrodzenia. Zazwyczaj jego wysokość jest uzależniona od liczby sprzedanych polis. Usługa assistance prawnego może okazać się atrakcyjna nie tylko dla ubezpieczycieli, ale również samych ubezpieczonych. Wynika to z faktu, że ubezpieczyciele, dążąc do zachowania klienta, oferują assistance prawny jako produkt komplementarny, z którego ubezpieczony może skorzystać także w przypadku negatywnego stanowiska w sprawie wypłaty odszkodowania z tytułu ubezpieczenia ochrony prawnej. W takim przypadku ubezpieczony może otrzymać przygotowany dla niego wzór pisma przedsądowego lub procesowego, co ułatwia mu prowadzenie sporu. Ułatwiony dostęp do porad prawnych w ramach assistance prawnego pozwala też na uniknięcie ewentualnych następstw działań ubezpieczonych przez możliwie szybkie uzyskanie przez nich informacji na temat ewentualnych konsekwencji. Przy korzystaniu z tego typu usług należy jednak pamiętać, że nie są one zazwyczaj świadczone przez radców prawnych oraz adwokatów, w związku z czym poziom takich porad należy uznać za zróżnicowany.

Dopuszczalność świadczenia usług asysty prawnej bywa niekiedy podawana w wątpliwość. Najczęściej jako podstawę krytyki wskazuje się w tym przypadku naruszenie art. 3 udu. Zgodnie z art. 3 ust. 2 udu ubezpieczyciel nie może wykonywać działalności innej niż działalność ubezpieczeniowa oraz bezpośrednio z nią związanej. Pojęcie działalności ubezpieczeniowej zostało 
zdefiniowane w art. 3 ust. 1 udu i jest rozumiane jako wykonywanie czynności ubezpieczeniowych związanych z oferowaniem i udzielaniem ochrony na wypadek ryzyka wystąpienia skutków zdarzeń losowych. Taki zarzut wydaje się na pierwszy rzut oka uzasadniony. Wątpliwości mogą pojawić się, kiedy brzmienie art. 3 ust. 1 udu zestawimy z art. 805 § 2 pkt 1 Ustawy kodeks cywilny (dalej: kc) definiującym świadczenie zakładu ubezpieczeń w ramach ubezpieczenia majątkowego. Zgodnie ze wskazanym wyżej przepisem świadczenie ubezpieczyciela polega w szczególności na zapłacie określonego odszkodowania za szkodę powstałą wskutek przewidzianego w umowie wypadku. Użyte sformułowanie „W szczególności” wskazuje, że świadczenie polegające na zapłacie odszkodowania jest wprawdzie świadczeniem zasadniczym, ale jak trafnie zauważa Szmak (2012: 78-79), nie jest świadczeniem wyłącznym. Także na gruncie innych ubezpieczeń pojawiają się takie świadczenia dodatkowe, niebudzące już tak licznych kontrowersji w doktrynie prawa ubezpieczeń, jak wspomniana wyżej informacja prawna. Przykładem takiego świadczenia może być chociażby szeroko rozpowszechniona usługa assistance samochodowego czy też zapewnienie samochodu zastępczego $\mathrm{w}$ ramach ubezpieczenia autocasco. Należy więc przyjąć, że również w przypadku asysty prawnej bezzasadne będzie powoływanie się na naruszenie w tym punkcie art. 3 udu. Ten zarzut będzie tym bardziej pozbawiony podstaw, że istniejąca już praktyka rynkowa wskazuje, że co do zasady zakłady ubezpieczeń dokonują outsourcingu usług asysty prawnej, którą zajmują się wyspecjalizowane podmioty.

Drugim formułowanym przez krytyków zastrzeżeniem jest naruszenie Ustawy prawo o adwokaturze oraz Ustawy o radcach prawnych. Wydaje się jednak, że także ten zarzut nie znajduje oparcia w istniejącym stanie prawnym. Wprawdzie niewątpliwie obie ustawy regulują zawody zaufania publicznego, których przedstawiciele mają pewne specjalne uprawnienia w ramach świadczenia usług prawnych, jednak żaden z ich przepisów nie wprowadza monopolu na świadczenie przez te dwie grupy szeroko rozumianych usług prawniczych. Przepisów zastrzegających konkretne dziedziny dla poszczególnych zawodów prawniczych możemy poszukiwać na gruncie przepisów formalnoprawnych, jednak i w tym przypadku znajdziemy tylko jeden przepis: art. 82 Ustawy kodeks postępowania karnego (dalej: kpk) monopolizujący pozycję adwokatów jako obrońców na gruncie postępowania karnego. Takich przepisów brakuje natomiast $\mathrm{w} \mathrm{kpc}, \mathrm{w}$ kodeksie postępowania administracyjnego (dalej: kpa) czy w Ustawie prawo o postępowaniu przed sądami administracyjnymi. Co więcej, nie rozwijając $w$ tym miejscu problematyki dopuszczalnej reprezentacji, moż- 
na tytułem przykładu wskazać art. $33 \S 1$ kpa, który expressis verbis stanowi, że pełnomocnikiem strony może być osoba fizyczna mająca zdolność do czynności prawnych. Tym bardziej w ramach szeroko rozumianego postępowania przedsądowego nie występują przepisy zakazujące świadczenia szeroko pojętych usług prawnych (np. pisania wzorów umów, regulaminów itd.) osobom nieprzynależącym do samorządów radcowskiego czy adwokackiego. Kierując się przyjętą na gruncie prawa polskiego oraz europejskiego zasadą in dubio pro liberte, należy przyjąć, że podejmowanie takiej działalności jest co do zasady dopuszczalne, skoro nie istnieje żaden przepis zakazujący jej prowadzenia.

\section{REPREZENTOWANIE PRZEZ ZAKŁAD UBEZPIECZEŃ}

Za oddzielny problem należy uznać kwestię reprezentowania ubezpieczonego przez zakład ubezpieczeń. Nie negując tezy, zgodnie z którą przez sam fakt korzystania z usług czy też zatrudniania profesjonalnych pełnomocników zakład ubezpieczeń jako taki nie nabywa uprawnień do reprezentowania ubezpieczonego, można jednak wskazać sytuację, w której w ramach procesu cywilnego, na podstawie unormowań kodeksowych, zakład ubezpieczeń stanie się pełnoprawnym pełnomocnikiem ubezpieczonego. Taka sytuacja może mieć miejsce w przypadku, gdy zakład ubezpieczeń przystąpi do procesu jako interwenient uboczny z mocy art. $76 \mathrm{kpc}$. Działanie interwenienta ubocznego możemy uznać za analogiczne do działania pełnomocnika, gdyż po pierwsze, zgodnie $\mathrm{z}$ art. $79 \mathrm{kpc}$, interwenientowi przysługują wszelkie uprawnienia dopuszczalne ze względu na stan sprawy, o ile nie są sprzeczne z działaniami i oświadczeniami strony, do której przystąpił. Należy jednocześnie założyć, że interwencja uboczna będzie możliwa zawsze wtedy, kiedy wynik sprawy będzie wpływał, nawet potencjalnie, na odpowiedzialność ubezpieczyciela. Wydaje się więc, że taka regulacja stanowi skuteczne obejście przepisu art. 3 udu, gdyż zakład ubezpieczeniowy, chroniąc swoją sferę interesów prawnych, chroni jednocześnie interes klienta.

Podsumowując niniejszą część, można powiedzieć, że zasadne wydaje się stwierdzenie, iż mimo szerokiej i wielokierunkowej krytyki świadczenia przez zakład ubezpieczeniowy usług prawnych, bez względu na pobudki, jakie mogą kierować takimi działaniami, bezpodstawne jest wskazywanie bezprawności takich działań - zarówno w oparciu o przepisy Ustawy o działalności ubezpieczeniowej, jak i ustaw regulujących zawody adwokata czy też radcy prawnego. 


\section{ETAP PRZEDSĄDOWY}

Ustawodawca krajowy, w ślad za ustawodawcą unijnym, uznaje za minimalny standard swobody wyboru pełnomocnika etap sądowy lub etap postępowania przed organem administracji, dając jednocześnie stronom umowy ubezpieczenia swobodę uregulowania tej kwestii na etapie przedsądowym. Określenie końca etapu przedsądowego ma niezwykle istotne znaczenie dla praktyki ubezpieczeniowej zakładów oferujących ubezpieczenia ochrony prawnej. Wyznacznikiem w tej sprawie będą jednak nie przepisy prawa materialnego, a prawa procesowego.

Z uwagi na ograniczenia wynikające z przyjętej formy artykułu nie będę poruszał problematyki odnoszącej się do postępowania karnego oraz postępowania cywilnego, a skupię się na zagadnieniach związanych z postępowaniem administracyjnym.

Rozpoczynając rozważania od problematyki postępowania administracyjnego, należy wskazać, że takie postępowanie - zgodnie z art. $61 \S 1 \mathrm{kpa}$ - jest wszczynane na wniosek lub z urzędu. W związku z tym momentem warunkującym obowiązek zapewnienia swobody wyboru pełnomocnika będzie bądź to wydanie postanowienia przez organ administracji, bądź to złożenie stosownego wniosku. Na gruncie literalnej wykładni art. 14 ust. 2 udu zakład ubezpieczeń może ograniczyć prawo wyboru pełnomocnika nawet na etapie tworzenia inicjującego postępowanie wniosku. Wydaje się jednak, że na aprobatę zasługuje pogląd Janygi (2010: 124), który wskazuje, że zasadę swobody wyboru pełnomocnika należałoby rozciągnąć także na etap bezpośrednio poprzedzający postępowanie przed organem administracji, a więc na sporządzenie wniosku. Trzeba również podkreślić, że literalna wykładnia art. 14 ust. 2 udu pozwala na przyjęcie tezy, zgodnie z którą nie znajduje on zastosowania na etapie między wydaniem decyzji ostatecznej przez organ administracji a wniesieniem skargi do sądu administracyjnego, gdyż nie mamy wtedy do czynienia ani z postępowaniem sądowym (jeszcze niewszczętym), ani z postępowaniem administracyjnym (już zakończonym). Rozwiązaniem tego problemu byłoby przyjęcie zasady, według której w przypadku zajścia w ramach jednego zdarzenia ubezpieczeniowego przesłanki warunkującej powstanie obowiązku respektowania przez ubezpieczyciela zasady swobodnego wyboru pełnomocnika, to trwałby on aż do końca sporu. Przyjęcie przeciwnego założenia mogłoby doprowadzić do kuriozalnych sytuacji, w których ubezpieczony miałby prawo do wyboru własnego pełnomocnika w ramach prowadzonego postępowania administracyjnego, 
przy czym straciłby je na okres, w którym może złożyć odwołanie do sądu administracyjnego, a odzyskałby je w momencie złożenia takiego odwołania.

\section{PEŁNOMOCNIK W ROZUMIENIU ART. 4 DYREKTYWY OP}

Ustawa o działalności ubezpieczeniowej, w ślad za dyrektywą OP, nie stanowi o pełnej dowolności wyboru pełnomocnika w tym znaczeniu, że może nim być na mocy polskiej ustawy radca prawny lub adwokat. Zestawienie brzmienia art. 14 ust. 2 udu z brzmieniem art. 4 dyrektywy OP pozwala na stwierdzenie, że stanowi on niepełną lub wadliwą implementację przepisu dyrektywy ze względu na zapewnienie swobody wyboru pełnomocnika w zakresie węższym, niż zostało to przewidziane w dyrektywie. Zgodnie z brzmieniem art. 14 ust. 2 udu ubezpieczony ma prawo swobodnego wyboru adwokata lub radcy prawnego. Jasno wynika stąd, że swoboda wyboru pełnomocnika innego niż radca prawny czy adwokat nie jest na gruncie tego przepisu dopuszczalna, nawet w sytuacji, kiedy dopuszczają ją przepisy proceduralne. Odmiennie kwestia ta została uregulowana w dyrektywie OP, według której prawo wyboru pełnomocnika dotyczy pełnomocnika będącego prawnikiem lub innej osoby uprawnionej do reprezentowania strony. Przy czym termin „prawnik” jest rozumiany zgodnie z art. 1 ust. 2 dyrektywy 77/249/EWG z dnia 22 marca 1977 roku, mającej na celu ułatwienie skutecznego korzystania przez prawników ze swobody świadczenia usług, a więc w Polsce jako adwokat i radca prawny. Wynika stąd jednoznaczny wniosek, że dokonana implementacja jest niepełna i nie realizuje właściwie założeń dyrektywy.

Istotne jest też pytanie, jakie podmioty mogą być uprawnione do reprezentowania w rozumieniu art. 4 dyrektywy OP. Odpowiedzi na nie należy poszukiwać wśród regulacji formalnoprawnych, a więc kpk, kpc, Ustawy prawo o postępowaniu przed sądami administracyjnymi oraz kpa.

Wydaje się, że najwięcej wątpliwości dotyczących poprawności implementacji dyrektywy OP pojawia się na gruncie postępowania cywilnego oraz administracyjnego. Zgodnie z art. 87 § 1 kpc podmiotami uprawnionymi do reprezentowania strony są adwokat lub radca prawny, a w sprawach własności przemysłowej także rzecznik patentowy, a ponadto osoba sprawująca zarząd nad majątkiem lub interesami strony, osoba pozostająca ze stroną w stałym stosunku zlecenia, jeżeli przedmiot sprawy wchodzi w zakres tego zlecenia, współuczestnik sporu, jak również rodzice, małżonek, rodzeństwo lub zstępni strony oraz osoby pozostające ze stroną w stosunku przysposobienia. Tytułem przy- 
kładu można także wskazać regulacje szczególne, np. art. 87 § 5 kpc, zgodnie z którym w sprawach związanych z ochroną praw konsumentów pełnomocnikiem może być przedstawiciel organizacji, do której zadań statutowych należy ochrona konsumentów. Jeszcze szerzej ujęty został katalog podmiotów uprawnionych do reprezentowania na gruncie postępowania administracyjnego art. $33 \S 1$ kpa wskazuje, że uprawnionym do reprezentowania jest osoba fizyczna posiadająca zdolność do czynności prawnych. Należy jednak podkreślić, że zgodnie z orzeczeniem Trybunału Sprawiedliwości Unii Europejskiej C-293/10 z dnia 26 maja 2011roku dopuszczono zawężenie pojęcia pełnomocnika jedynie do pełnomocników profesjonalnych. Wydaje się jednak, że to nie kwestia nieprofesjonalnych pełnomocników stanowi zasadniczy problem. Wątpliwości budzi zwłaszcza pominięcie profesjonalnych pełnomocników, wymienionych w art. $87 \S 1$ kpc, którymi są rzecznicy patentowi. Można wskazać, że wprawdzie są oni uprawnieni jedynie do reprezentowania w sprawach z zakresu praw własności przemysłowej, lecz są niewątpliwie profesjonalnymi pełnomocnikami, których należy umiejscowić w zakresie zastosowania art. 4 dyrektywy OP.

Kolejnym ważnym zagadnieniem jest kwestia milczenia ustawy w sprawie prawników zagranicznych świadczących usługi prawnicze na terytorium Rzeczypospolitej Polskiej na podstawie przepisów Ustawy o świadczeniu przez prawników zagranicznych pomocy prawnej w Rzeczypospolitej Polskiej (dalej: uśp). W niniejszej publikacji zrezygnuję ze szczegółowego opisu sytuacji prawników z krajów Unii Europejskiej, którzy wpisali się na listy adwokatów lub radców prawnych w Polsce, gdyż na mocy art. 14 uśp zastosowanie mają względem nich przepisy dotyczące odpowiednio adwokatów lub radców prawnych, z tym jednak zastrzeżeniem, że zgodnie z art. 8 uśp taki prawnik używa tytułu zawodowego uzyskanego w państwie macierzystym, wyrażonego w języku urzędowym tego państwa. Także w odniesieniu do prawników z Unii Europejskiej świadczących transgraniczne usługi prawnicze zastosowanie znajduje norma art. 14 ust. 2 udu, gdyż - zgodnie z art. 36 ust. 1 uśp - świadcząc usługi polegające na reprezentowaniu klienta w postępowaniu przed sądami i innymi organami władzy publicznej, prawnik z Unii Europejskiej podlega tym samym warunkom wykonywania zawodu, jakie stosuje się do adwokata lub radcy prawnego, z wyjątkiem warunków dotyczących miejsca zamieszkania i wpisu na listę adwokatów lub radców prawnych.

Problemem może być jednak prowadzenie stałej praktyki przez prawników spoza Unii Europejskiej. Uśp nie zawiera przepisu, zgodnie z którym stosuje się do nich bezpośrednio przepisy o adwokaturze lub radcach prawnych. Co wię- 
cej, zgodnie z art. 18 uśp, ich uprawnienia ograniczają się do wydawania opinii i udzielania porad dotyczących prawa państwa macierzystego lub prawa międzynarodowego. Art. 14 ust. 2 udu przewiduje prawo do swobody wyboru pełnomocnika, a więc osoby uprawnionej do reprezentowania ubezpieczonego. Z uwagi na to, że prawnik spoza Unii Europejskiej prowadzący stałą praktykę nie ma takiego uprawnienia, uzasadnione wydaje się zanegowanie prawa swobodnego wyboru pełnomocnika w przypadku tych prawników.

Praktyczne rozstrzygnięcie omawianych powyżej wątpliwości będzie miało, w mojej opinii, doniosłe znaczenie dla prowadzonej przez zakłady ubezpieczeń działalności w zakresie ubezpieczeń ochrony prawnej. Istotne rozszerzenie katalogu pełnomocników, wobec których znajdzie zastosowanie zasada swobody wyboru pełnomocnika, może wpłynąć na wysokość składki ubezpieczeniowej. To z kolei może mieć teoretycznie wpływ na popularność tego produktu. Należy wskazać, że ubezpieczenia ochrony prawnej nie są jeszcze zbyt popularne wśród Polaków. Po części wynika to z pewnej awersji do przedłużających się procesów sądowych oraz z przekonania, że w razie konieczności wystąpienia na drogę sądową to sąd udzieli porad dotyczących podjęcia działań koniecznych do pozytywnego rozstrzygnięcia sprawy. Wydaje się jednak, że takie zachowania powoli odchodzą w przeszłość, ustępując miejsca wyższemu poziomowi kultury prawnej. Przyjęcie takiego założenia pozwala uznać, że nawet wzrost wysokości składek ubezpieczeniowych spowodowany właściwym wdrożeniem postanowień dyrektywy OP nie powinien istotnie wpłynąć na rozwój tego typu ubezpieczeń. Tę tezę można oprzeć na obserwacji, zgodnie z którą nawet podniesione składki ubezpieczeniowe pozostawałyby w znaczącej dysproporcji, na korzyść ubezpieczenia, do ewentualnego finansowania pełnomocników bezpośrednio przez samego zainteresowanego.

\section{ZAKOŃCZENIE}

Mimo dynamicznego rozwoju rynku ubezpieczeń ochrony prawnej brakuje szerszego zainteresowania praktyków związanymi z nim problemami prawnymi. Jednocześnie zakłady ubezpieczeń nie znajdują zbyt licznych wskazówek ustawodawcy krajowego dotyczących kształtowania relatywnie nowego produktu na polskim rynku. Sama regulacja art. 14 udu dokonuje niepełnej implementacji przepisów dyrektywy OP. Wydaje się, że wraz z dalszym rozwojem rynku konieczne będzie podjęcie szerszej dyskusji na temat rozbudowy regulacji dotyczących tego produktu ubezpieczeniowego w oparciu o wzorce kra- 
jów mających bogate doświadczenie w tym zakresie, a więc przede wszystkim Austrii i Niemiec.

W literaturze wskazuje się, że to właśnie zasadzie swobody wyboru pełnomocnika należy przypisywać ogromny sukces ubezpieczeń OP w Austrii i w Niemczech (Vassel, Mierzejewski 2005: 34). W związku z tym wydaje się, że rozszerzenie katalogu pełnomocników m.in. o rzeczników patentowych będzie skutkowało umocnieniem się pozycji rynkowej ubezpieczeń ochrony prawnej. Mimo dotychczasowego dynamicznego wzrostu nie mają one istotnego udziału w rynku ubezpieczeń.

\section{IITERATURA}

Budzisiak S. (2011), Potrzebna edukacja, Miesięcznik Ubezpieczeniowy, nr 12.

Dyrektywa Rady z dnia 22 czerwca 1987 r. w sprawie koordynacji przepisów ustawowych, wykonawczych i administracyjnych odnoszących się do ubezpieczenia ochrony prawnej (Dz.U. L 185 z 4.07.1987 r.).

Janyga B. (2010), Komentarz do art. 14 Ustawy o działalności ubezpieczeniowej, [w:] Prawo ubezpieczeń gospodarczych. Komentarz, t. 1, Z. Brodecki, M. Serwach, M. Gilcz (red.), Wolters Kluwer Polska, Warszawa.

Janyga B. (2011), Likwidacja szkód, Miesięcznik Ubezpieczeniowy, nr 12.

Janyga B., Dittmajer M. (2005), Ubezpieczenie ochrony prawnej jako szansa zwiększenia dostępu obywateli do pomocy prawnej, Radca Prawny, nr 3.

Szmak S. (2012), Wybór prawnika w ubezpieczeniu ochrony prawnej-regulacje wybranych państw europejskich oraz orzecznictwo Trybunału Sprawiedliwości UE, Prawo Asekuracyjne, nr 2.

Szywalski R. (2011), Polisa LEGO, Miesięcznik Ubezpieczeniowy, nr 12.

Ustawa z dnia 23 kwietnia 1964 r. Kodeks cywilny, Dz.U. z 1964 r., nr 16, poz. 93.

Ustawa z dnia 14 czerwca 1960 r. Kodeks postępowania administracyjnego, Dz.U. z 2000 r., nr 98, poz. 1071.

Ustawa z dnia 17 listopada 1964. Kodeks postępowania cywilnego, Dz.U. z 1964 r., nr 43, poz. 296.

Ustawa z dnia 6 czerwca 1997 r. Kodeks postępowania karnego, Dz.U. z 1997 r., nr 89, poz. 555.

Ustawa z dnia 22 maja 2003 r. o działalności ubezpieczeniowej, Dz.U. z 2010 r., nr 11, poz. 66.

Ustawa z dnia 5 lipca 2002 r. o świadczeniu przez prawników zagranicznych pomocy prawnej w Rzeczypospolitej Polskiej, Dz.U. z 2002 r., nr 126, poz. 1069.

Ustawa z dnia 30 sierpnia 2002 r. Prawo o postępowaniu przed sądami administracyjnymi, Dz.U. z 2012 r., nr 270.

Vassel J., Mierzejewski P. (2005), Ubezpieczenie ochrony prawnej w Europie i Polsce, Prawo Asekuracyjne, nr 1. 